\title{
Enhancing Colour Appearances of Cultivated 15 Year-old Acacia Hybrid through Oil Heat Treatment Process
}

\author{
Izyan Khalid \\ University Malaysia Sabah, 88999, Kota Kinabalu, Sabah, Malaysia \\ Tel: 60-1-2400-5712 E-mail: izyankhalid82@hotmail.com \\ Razak Wahab (Corresponding author) \\ University Malaysia Sabah, 88999, Kota Kinabalu, Sabah, Malaysia \\ Tel: 60-1-6836-6055 E-mail: drrazakw@ums.edu.my \\ Othman Sulaiman \\ Universiti Sains Malaysia, 11800 Penang, Malaysia \\ Tel: 60-1-6470-8134 E-mail: Othman@usm.my \\ Aminuddin Mohamed \\ University Malaysia Sabah, 88999, Kota Kinabalu, Sabah, Malaysia \\ Tel: 60-1-3851-8505 E-mail: aminuddin@ums.edu.my \\ Tamer A. Tabet \\ University Malaysia Sabah, 88999, Kota Kinabalu, Sabah, Malaysia \\ Tel: 60-1-9813-0200Ｅ-mail: tamertbt@ums.edu.my \\ Roziela Hanim Alamjuri \\ University Malaysia Sabah, 88999, Kota Kinabalu, Sabah, Malaysia \\ Tel: 60-1-9843-5492 E-mail: rhanim@ums.edu.my
}

The research was financed by The Ministry of Science, Technology and Invention, Malaysia, under the Science Fund Project SCF0037-IND-1/2007.

\begin{abstract}
This study investigated the effect of oil heat treatment process on colour appearance of cultivated Acacia hybrid. Parameters such as temperatures and treatment time are taken in account due to their influences in enhancing the colour changes of the natural untreated and oil heat treated of the wood from the sapwood right trough the heartwood. Young, natural and untreated A. hybrid would normally have the sapwood having lighter colour than the dark colour heartwood. Turning these timbers into plywood or furniture at this stage will result in uneven colour as the results of the mixture between the sapwood and heartwood. This will decrease the value of the products. Heating the wood at varying temperatures and treatment time would enhance the colour appearance of the young wood. The colour changes in the sapwood and heartwood were measured using Minolta Chroma-meter CR-310 and the results are presented according to the CIE L*a*b* colour co-ordinates system. The results revealed that the rising temperature at certain duration resulted in enhancing and darkening of wood tissues.
\end{abstract}

Keywords: Oil heat treatment, High temperature, Duration, Colour appearance, Acacia hybrid and sapwood 


\section{Introduction}

Acacia species has becomes one of major plantation species in the forest plantation project in Malaysia. The project started in 1982, aim in sustainable supplying of timbers to the local wood-based industry. The wood-based industry is expected to face a shortfall from the natural forests (Shakri, 1995). Acacia was chosen as a plantation species based on its quick growth, adaptability to local soil condition and the quality of wood it produced. Acacia is also highly appreciated for its quality in producing exquisite furniture with lasting values at affordable cost. The furniture is valued mostly based on its strength, durability and aesthetic value such as grain orientation and colours.

However, young Acacia has a higher proportion of distinct colour different between the sapwood and heartwood. The sapwood's colour is lighter than heartwood. These colour differences with definite irregular colour margins reduce the value of wood considerably. Serious marketing problem could occur when matching pair individual pieces with different colour components into final products. In order to achieve a competitive market, the colour appearance of the wood need to be technically modified for evaluating the quality of the products (Tolvaj et al., 2006). The sapwood of all timber species can be enhanced by using the heating process (Charrier et al., 2002).

Heat treatment seemed to be a suitable treatment for woods because of its advantage to be environment friendly process because of non toxin and does not require chemicals. Most woods treatment used preservative, which mostly have heavy metals and discharge toxin to the environment. A lot of effort has been put to develop new wood preservatives. In addition, developed countries have totally banned the use of Chrome-copper Arsenic (CCA) in their woody materials (Berard et al., 2006). In recent years, advanced in environmental awareness and the effective of policies which support the use of renewable resources and environment-friendly chemicals have resulted in high interest in non-biocides. Another environment friendly technique is the use of biogradable substances in wood protection (Hyvonen et al., 2006).

The objective of this study was to investigate how oil heat treatment process enhanced $A$. hybrid wood colour appearance at different temperature treatment time. The result of this study will benefit immensely in terms of improving the technologies in treated wood for the local wood industry in producing uniform and good quality of Acacia products.

\section{Material and Methodology}

\subsection{Wood material}

Three defects free of 15 years old A. hybrid (Acacia mangium x Acacia auriculiformis) trees were obtained from a forest plantation at Sabah Forest Development Authority (SAFODA), Kinarut, Kota Kinabalu, Sabah. The logs were harvested from trees selected based on their good physical appearances, diameters of the trees at breast height ranged from 25 to $30 \mathrm{~cm}$., long straight bole and with minimum branches. The logs were cut and segregated into bottom, middle and top portions. Boles of $600 \mathrm{~mm}$ long were cut from the middle of each portion and later planed into size of $320 \mathrm{~mm}$ x $100 \mathrm{~mm}$ x $25 \mathrm{~mm}$ (length x width x thickness). After drying, the bolts were cut open in the middle by using chainsaw and planned of size $300 \mathrm{~mm} \times 100 \mathrm{~mm}$ x $25 \mathrm{~mm}$ (length $\mathrm{x}$ width $\mathrm{x}$ thickness). The samples were placed in a condition chamber at $20^{\circ} \pm 3^{\circ} \mathrm{C}$ and $65 \pm 5 \%$ relative humidity to stabilize the moisture content prior to treatment.

\subsection{Oil-heat Treatment Process}

The oil heat treatment on A. hybrid wood was performed in a stainless steel tank, complete with the thermocouples and heat generator. The tank size used in this study is $30 \mathrm{~cm} \mathrm{x} 10 \mathrm{~cm} \mathrm{x} 25 \mathrm{~cm}$ (length $\mathrm{x}$ width $\mathrm{x}$ height) and $3 \mathrm{~mm}$ thickness. The heat of the tank was generated by an electric power source. Eighty samples were prepared prior to the treatment. Crude cooking oil which is palm oil was used as heating medium. This oil was chosen because it is chemically free and has a high boiling point of $320^{\circ} \mathrm{C}$ (Rafidah, 2007). Treatment temperature at $180^{\circ} \mathrm{C}, 200^{\circ} \mathrm{C}$ and $220^{\circ} \mathrm{C}$ were applied at duration of 30,60 and 90 minutes. After each treatment period, the samples were removed out from the tank. The samples were cooled down and then conditioned in a conditioning chamber at $20^{\circ} \pm 3^{\circ} \mathrm{C}$ and $65 \pm 5 \%$ relative humidity. Treated sample were tested in accordance to the international standard procedures.

\subsection{Colour Measurement of Heat Treated Samples}

The colour measurement were taken when the wood samples had undgone the oil heat treatment at $180^{\circ} \mathrm{C}, 200^{\circ} \mathrm{C}$, $220^{\circ} \mathrm{C}$ and 30, 60, and 90 minutes respectively. Prior to the colour appearance analysis, the surface to be measured was marked before the heat treatment process. This was done so that the parts of the surface measured were consistent throughout the process. By using pencil, the marked point was done by $2 \mathrm{~cm} \times 2 \mathrm{~cm}$ at the cross-sectional surface of each sapwood and heartwood. This section was regarded as the most representative 
area for revealing the colour difference of sample (Unsal et al., 2003). The samples were sanded down slightly for about $3 \mathrm{~mm}$ with P100 sandpaper and brushed cleanly to minimize the risk of variation colour values cause by differences in surface structure.

The measurements of colour were determined according to CIE L*a*b* (1986) system for providing a more accurate and objective colour determination. A colour solid is defined by three rectangular coordinates. This system was sensitive enough to detect small differences in colour parameters to describe between tree and within species' variation (Thulasidas et al., 2006). The principal axis is the lightness level L* on a $0-100$ scale, 0 being total blackness and 100 pure white while intermediate values give grey shades. The hue is specified by the other two chromic characters $a^{*}$ and $b^{*}$. Where, $a^{*}$ is the red-green axis, with negative values reflecting the dominance of greenness and positive ones redness, and $b^{*}$ is the yellow-blue axis, with negative values reflecting the dominance of blueness and positive ones yellowness.

Changes in colour of the wood surface due to treatment were done by using a Minolta Chroma Meter CR-10. These measurements were only done on clear wood surfaces as stated before. The sensor head was $8 \mathrm{~mm}$ in diameter. The colour reader measures the colour difference on the surface of wood specimens between two colours which that before and after treatment. The results were presented according to the CIE $\mathrm{L} * \mathrm{a} * \mathrm{~b} *$ colour co-ordinates system base on the D65 light source with the reflection spectrum was measured in the $400-700 \mathrm{~nm}$ regions. These values were used to calculate the colour change as a function of heat treatment according to the 1 , 2 and 3 respectively.

$$
\begin{aligned}
& \mathrm{L}_{\mathrm{t}}{ }^{*}=\mathrm{L}_{\mathrm{t}}{ }^{*}-\mathrm{L}_{\mathrm{s}}{ }^{*} \\
& \mathrm{a}_{\mathrm{t}}{ }^{*}=\mathrm{a}_{\mathrm{t}}{ }^{*} \mathrm{a}_{\mathrm{s}}{ }^{*} \\
& \mathrm{~b}_{\mathrm{t}}{ }^{*}=\mathrm{b}_{\mathrm{t}}{ }^{*}-\mathrm{b}_{\mathrm{s}}{ }^{*}
\end{aligned}
$$

Where, $\mathrm{t}=$ treated sample, $\mathrm{s}=$ control sample at $\mathrm{t} \Delta=$ colour change

\section{Results and Discussion}

\subsection{Colour Appearances}

Based on the colour measurement of both the sapwood and heartwood, the effect on colour through oil heat treatment can be noticed obviously at different treatment temperature and treatment time, in comparison to the original color of the specimen. Changes in $\mathrm{L}^{*}, \mathrm{a}^{*}$ and $\mathrm{b}^{*}$ were affected by treatment temperature, duration of the time exposed and wood types while the change in colour with sampling height did not show any significant difference. Treatment temperature at $200^{\circ} \mathrm{C}$ and treatment time of 90 minutes and $220^{\circ} \mathrm{C}$ at 30 minutes of the sapwood are effective in uniforming the colour of wood to the original colour of the untreated heartwood.

\subsubsection{Lightness $\left(\mathrm{L}^{*}\right)$ of Wood Colour}

In this study, the main involvement of the chang in colour of both wood types is the lightness $\left(\mathrm{L}^{*}\right)$. As noted by Keey (2004), variation in $L^{*}$ is more responsive sign of colour change to the human eye that accompanying change in chromic characters a* and $\mathrm{b}^{*}$, while Thulasidas et al. (2006) reported that the variability in darkness or lightness is the main cause of wood colour variability.

Table 1 presents the colour changed values of treated sapwood and heartwood. From the chang in lightness ( $\left.\mathrm{L}^{*}\right)$ values, both sapwood and heartwood show the decreasing lightness at first 30 minutes of every treatment and it becomes progressively decreased with the increase of treatment temperature and duration. However the $\mathrm{L}^{*}$ values of heartwood did not changed considerably if compared to $L^{*}$ values of sapwood. This might be because of the brightness of the wood colour itself which that sapwood of Acacia has a brighter colour than heartwood.

Figures 1, 2 and 3, shows the colour of bottom, middle and top of Acacia boards treated at different temperatures and durations respectively. From the observation, sapwood becomes slightly darker, while heartwood becomes considerably darker when expos to vary treatment conditions. From the result obtained from bottom, middle and top portion of sapwood, wood treated at $220^{\circ} \mathrm{C}$ in 30 minutes showed $\mathrm{L}^{*}$ values almost have similar values with $\mathrm{L}^{*}$ values of untreated heartwood. This also can be observed obviously from the below figure shown (see Figures 4, 5 and 6).

From the result shown, the decreas in $\mathrm{L}^{*}$ values between $200^{\circ} \mathrm{C}-220^{\circ} \mathrm{C}$ was larger than $180^{\circ} \mathrm{C}$ in sapwood if compared to heartwood. The $\mathrm{L}^{*}$ values in heartwood slightly changed when the temperature exceeds $200^{\circ} \mathrm{C}$. The largest change of treatment duration of both wood types can be found between 60-90 minutes. This indicates the changed in $\mathrm{L}^{*}$ values gradually decreased with the increase of treatment temperature and longer duration. 
The summary of the correlation coefficient of colour variation with other wood properties of treated acacia is given in Table 2. According to Sundqvist (2004), the differences of chemical composition in wood such as extractive and lignin in sapwood and heartwood can probably be the main reason for dissimilar in colour. This reinforced by the research done by Burtin et al. (2000) where during steaming at elevated temperatures, polyphenol compounds found in hybrid walnut heartwood, which conferred the dark color to heartwood, may migrate in the sapwood region and change the sapwood colour from light to dark changes in wood colour.

Mitsui et al. (2001) and Bourgios et al. (1991) also reported that decreased in lightness was resulting from high temperature of heat treatment due to decrement in a certain chemical component in wood such as hemicellulose and lignin. Changes in wood colour can be an indication of chemical modification or changes in wood (Burtin et al. 2000; Bekhta and Niemz, 2003; Sundqvist et al. 2006).

\subsubsection{Chroma Colour, $\mathrm{a}^{*}$ (Reddish Colour)}

In the chroma coordinates, $\mathrm{a}^{*}$ and $\mathrm{b}^{*}$ are a combination of red $\left(\mathrm{a}^{*}\right)$ and yellow $\left(\mathrm{b}^{*}\right)$. Both of the wood type samples showed some differences due to the chang in $a^{*}$ and $b^{*}$ values. Figures 6 and 7 , shows that the change in red $\mathrm{a}^{*}$ values of sapwood and heartwood were totally different with the trends of the chart.

The $a^{*}$ values of sapwood was increased while $a^{*}$ values of heartwood decreased through this treatment. This might be because of the original colour of the wood samples itself. Original sapwood colour of Acacia hybrid is light yellowish red while heartwood colour is brownish red. Increased in treatment temperature tends to increase $\mathrm{a}^{*}$ values of sapwood. The $\mathrm{a}^{*}$ values reached maximum values after treated at $220^{\circ} \mathrm{C}$ temperature. Based on the $\mathrm{a}^{*}$ values, the colour of sapwood becomes redder than before while red colour in heartwood becomes lessen. According to Hon et al. (1991) the reddish colour and increased saturation substantiated as a decrease in hue and increase in chroma can be due to the formation of secondary condensation or degradation products of the quinine and quinonemethide types. According to Charrier et al. (2002) and Grelier et al. (1997), wood colours changed toward yellow to brown because of the photo-oxidation of lignin and wood extractives, with the production of coloured quinine component.

\subsubsection{Chroma Colour, $\mathrm{b}^{*}$ (Yellowish Colour)}

Figure 6 presents $b^{*}$ values of sapwood. $b^{*}$ values for sapwood begin to decrease with the increase of temperature and duration of treatments. $\mathrm{b}^{*}$ values of sapwood show the greater decreased when treated at $200^{\circ} \mathrm{C}-220^{\circ} \mathrm{C}$ and $60-90$-minute duration. From the observation in Figures 7, 8 and 9 respectively, the yellowish colour of sapwood becomes faded and turns to brownish yellow.

The $b^{*}$ values of heartwood show the negative change from the start of the treatment (Figure 9). This means that the yellowish colour in heartwood start to decrease from $180^{\circ} \mathrm{C}$ and it decreases drastically when exposed to $220^{\circ} \mathrm{C}$ and longer treatment duration.

There was a correlation between $\mathrm{b}^{*}$ and $\mathrm{a}^{*}$ of $A$. hybrid wood (Table 2). Positive correlations were observed between $\mathrm{a}^{*}$ and $\mathrm{b}^{*}$.

\subsection{Analysis of Variance on Colour Appearances}

The summary of ANOVA of colour appearances of treated Acacia is given in Table 2. The change in lightness $\left(\mathrm{L}^{*}\right)$ through oil heat treatment were highly significant affected by treatment temperature, duration, wood types and sampling height. This means that $\mathrm{L}^{*}$ play a significant role in the treatment in indicating the changed of wood colour. However for chroma colour ( $a^{*}$ and $b^{*}$ ) only wood types showed the significant difference. This concludes that chroma colour did not influence much in the changed of wood colour through this treatment.

\section{Conclusion}

The sapwood and heartwood of A.hybrid colour becomes darker once they are exposed to the high temperature and longer treatment time in oil heat treatment process. The degree of the changes varies between both wood types. The sapwood tends to darken more than the heartwood. The increment in colour of both woods increases with temperature and treatment time.

The lightness $\left(\mathrm{L}^{*}\right)$ values, both sapwood and heartwood decrease with the increase in the treatment temperature and treatment time. The $\mathrm{L}^{*}$ values for the heartwood did not changed considerably when compared to $\mathrm{L}^{*}$ values of sapwood. The $\mathrm{L}^{*}$ value are tremendously affected by the treatment where there are changes in $\mathrm{a}^{*}$ and $\mathrm{b}^{*}$ values.

The increase in treatment temperature tends to decrease $\mathrm{L}^{*}$ and drastically increase the $\mathrm{a}^{*}$ values of wood. The decrease of $L^{*}$ values causes the darkening of the wood surfaces while the increased values in a* caused the wood colour becomes more red and decreases in $b^{*}$ values caused the decrease yellow colour of wood turn into 
brownish colour. The temperature rather than the treatment time is the most important process variable in controlling the final colour of the treated wood.

Changes in $\mathrm{L}^{*}, \mathrm{a}^{*}$ and $\mathrm{b}^{*}$ were affected by treatment temperature, duration of the time exposed and wood types while the changed in colour with sampling height did not show any significant difference. Treatment temperature at $200^{\circ} \mathrm{C}$ and treatment time of 90 minutes and $220^{\circ} \mathrm{C}$ at 30 minutes of the sapwood are effective in uniforming the colour of wood to the original colour of the untreated heartwood.

Oil heat treatment induced extensive darkening and reddening of $A$. hybrid wood. This technology can be used to modify acquiring darker tonality of wood to suit the consumers demand.

\section{References}

Bekhta, P. and Niemz, P. (2003). Effect of High Temperature on the Change in Color, Dimensional Stability and Mechanical Properties of Spruce Wood. Journal of Holzforschung, Vol. 57: 539-546.

Berard, P., Laurent, T. and Dumonceaud, O. (2006). Use of Round Wood of Chestnut Tree Coppices: Crack Risk and Effects of a Hot Oil Bath Treatment. Journal of Holz als Roh-und Werkstoff, Vol 64: 287-293. DOI 10.1007/s00107-005-0086-4.

Bourgois, P.J., Janin, G. and Guyonnet, R. (1991). La Mesure de Couleur. Une Methode d'Etude et d' Optimisation des Transformations Chimiques du Bois Thermolyse. Journal of Holzforchung, Vol 45:377-382.

Burti, P., Jay-Allemand, C., Charpentier, J. P. and JANIN, G. (1998). Natural Wood Colouring Process in Juglans Spp. (J.nigra, J.regia, and Hybrid J. nigra x J. regia) Depends on Native Phenolic Compounds Accumulated in the Transition Zone between Sapwood and Heartwood. Journal of Trees. 12:258-264.

Charrier, B., Charrier, F., Janin, G., Kamdem, D.P., Irmouli, M. and Goncalez, J. (2002). Study of Industrial Boiling Process on Walnut Colour: Experimental Study Under Industrial Conditions. Journal of Holz als Roh-und Werkstoff, Vol 60: 259-264. DOI 10.1007/s00107-005-0082-8.

Grelier, S., Castellan, A., Desrousseaux, S., Nour, A, Ode, A. and Podgorski, L. (1997). Attempt to Protect Wood Colour Against UV/Visible Light by Using Antioxidants Bearing Isocyanate Groups and Grafted to the Material with Microwave. Journal of Holzforschung. 51: 511-518.

Hon, D. N. S. and Minemura, N. (1991). Color and Discoloration. In Hon, D. N. S. and Shirashi, N. (ed.) Wood and Cellulosic Chemistry, pp.395-454. New York: Marcel Dekker Inc.

Hyvonen, A., Piltonen, P. and Niinimaki, J. (2006). Tall Oil/Water- Emulsions as Water Repellents for Scots Pine Sapwood. Journal of Holz als Roh-und Werkstoff, Vol 64: 68-73. DOI 10.1007/s00107-005-0040-5.

Mitsui, K., Takada, H., Sugiyama, M. and Hasegawa, R. (2001). Changes in the Properties of Light-Irradiated Wood with Heat Treatment. Part 1. Effect of Treatment Conditions on the Change in Color. Journal of Holzforschung, Vol 55: 601-605.

Rafidah, M.D. (2007). Effect of high temperature boiling on properties of Gigantochloa scortechnii gamble (Buluh Semantan). Master Thesis. Universiti Putra Malaysia, Malaysia.

Shakri, M.S. (1995). Finishing Properties of Acacia mangium, Paraserianthes falcataria and Gmelina arborea Timbers: Some Important Parameters. Journal of Tropical Forest Products, Vol 1(1): 83-89.

Stenudd, S. (2003). Colour Response of Silver Birch to Press Drying. Proceedings of the 8th International IUFRO Wood Drying Conference. August 24 - 29, 2003. Brasov, Romania. 449-454.

Sundqvist, B. (2004). Colour changes and acid formation in wood during heating. Ph.D. Thesis. Lulea University of Technology. 
Table 1. Average values of colour variation in L*, a* and b* of oil heat-treated Acacia hybrid wood

\begin{tabular}{|c|c|c|c|c|c|c|c|c|c|c|c|}
\hline \multirow{2}{*}{$\begin{array}{l}\text { Wood } \\
\text { types }\end{array}$} & \multirow{2}{*}{$\begin{array}{c}\text { Temp. } \\
\left({ }^{\circ} \mathrm{C}\right)\end{array}$} & \multirow{2}{*}{$\begin{array}{l}\text { Treatment } \\
\text { duration } \\
\text { (min) }\end{array}$} & \multicolumn{3}{|c|}{$\mathrm{L}^{*}$} & \multicolumn{3}{|c|}{$a^{*}$} & \multicolumn{3}{|c|}{$b^{*}$} \\
\hline & & & B & $\mathrm{M}$ & $\mathrm{T}$ & B & $\mathrm{M}$ & $\mathrm{T}$ & B & M & $\mathrm{T}$ \\
\hline \multirow{10}{*}{ Sapwood } & Control & Control & 73.6 & 73.0 & 71.4 & 6.9 & 6.6 & 7.3 & 21.2 & 22.3 & 21.4 \\
\hline & & 30 & 66.7 & 70.0 & 65.5 & 7.4 & 8.7 & 8.5 & 21.9 & 23.3 & 23.4 \\
\hline & 180 & 60 & 65.4 & 62.7 & 63.0 & 8.8 & 9.9 & 9.8 & 25.7 & 26.3 & 24.1 \\
\hline & & 90 & 65.6 & 61.9 & 62.9 & 9.3 & 10.9 & 10.2 & 27.3 & 27.5 & 26.3 \\
\hline & \multirow{3}{*}{200} & 30 & 63.5 & 63.5 & 58.2 & 9.5 & 10.0 & 9.9 & 26.4 & 26.1 & 26.2 \\
\hline & & 60 & 56.9 & 57.2 & 56.9 & 11.4 & 11.9 & 10.7 & 27.5 & 27.1 & 26.5 \\
\hline & & 90 & 50.7 & 54.6 & 51.6 & 12.2 & 12.4 & 12.2 & 27.9 & 28.9 & 28.0 \\
\hline & \multirow{3}{*}{220} & 30 & 56.5 & 53.0 & 53.4 & 11.7 & 10.6 & 10.3 & 27.6 & 26.9 & 26.7 \\
\hline & & 60 & 48.7 & 47.9 & 43.2 & 12.3 & 12.7 & 11.2 & 27.8 & 27.6 & 27.8 \\
\hline & & 90 & 41.5 & 40.6 & 39.2 & 13.9 & 13.5 & 12.6 & 28.1 & 29.3 & 28.9 \\
\hline \multirow{10}{*}{ eartwood } & Control & Control & 54.1 & 54.8 & 53.5 & 14.2 & 15.1 & 13.9 & 26.8 & 26.3 & 25.2 \\
\hline & \multirow{3}{*}{180} & \multirow{3}{*}{$\begin{array}{l}30 \\
60 \\
90\end{array}$} & \multirow{3}{*}{$\begin{array}{l}53.6 \\
51.7 \\
50.4\end{array}$} & \multirow{3}{*}{$\begin{array}{l}52.7 \\
51.6 \\
50.2\end{array}$} & \multirow{3}{*}{$\begin{array}{l}52.9 \\
50.7 \\
48.2\end{array}$} & \multirow{3}{*}{$\begin{array}{l}13.4 \\
11.9 \\
11.2\end{array}$} & \multirow{3}{*}{$\begin{array}{l}12.9 \\
11.1 \\
10.8\end{array}$} & \multirow{3}{*}{$\begin{array}{l}12.0 \\
11.5 \\
10.7\end{array}$} & \multirow{3}{*}{$\begin{array}{l}25.0 \\
23.6 \\
23.0\end{array}$} & \multirow{3}{*}{$\begin{array}{l}24.8 \\
23.2 \\
21.5\end{array}$} & \multirow{3}{*}{$\begin{array}{l}24.1 \\
23.5 \\
22.3\end{array}$} \\
\hline & & & & & & & & & & & \\
\hline & & & & & & & & & & & \\
\hline & \multirow{3}{*}{200} & \multirow{2}{*}{30} & 51.4 & 52.1 & 48.6 & 11.5 & 10.3 & 11.3 & 23.7 & 24.1 & 23.9 \\
\hline & & & 49.1 & 50.5 & 46.9 & 11.0 & 9.7 & 10.7 & 23.4 & 21.5 & 21.9 \\
\hline & & $\begin{array}{l}00 \\
90\end{array}$ & 45.9 & 46.7 & 43.5 & 9.9 & 8.9 & 10.2 & 23.1 & 21.2 & 20.9 \\
\hline & & 30 & 50.7 & 50.8 & 46.3 & 10.0 & 9.0 & 10.2 & 22.6 & 22.9 & 21.0 \\
\hline & 230 & 60 & 46.6 & 47.4 & 38.8 & 8.3 & 8.3 & 8.4 & 21.1 & 19.8 & 17.2 \\
\hline & 220 & $\begin{array}{l}60 \\
90\end{array}$ & 40.0 & 40.9 & 33.1 & 6.7 & 7.1 & 7.3 & 20.5 & 19.0 & 15.1 \\
\hline
\end{tabular}

Note: $\quad$ Temp. = temperature

$\min =$ minutes

$\mathrm{L}^{*}=$ lightness

$\mathrm{a}^{*}=$ red

$\mathrm{b}^{*}=$ yellow

$\mathrm{B}=$ Bottom

$\mathrm{M}=$ Middle

$\mathrm{T}=\mathrm{Top}$ 
Table 2. ANOVA of colour appearances of treated Acacia hybrid

\begin{tabular}{|c|c|c|c|c|c|}
\hline $\begin{array}{l}\text { Source of } \\
\text { Variance }\end{array}$ & $\begin{array}{c}\text { Dependent } \\
\text { Variable }\end{array}$ & Sum of Squares & Df & Mean Square & F-Ratio \\
\hline \multirow{3}{*}{ Temperature } & $L^{*}$ & 9538.60 & 3 & 3179.53 & $110.70^{* *}$ \\
\hline & $a^{*}$ & 9.33 & 3 & 3.11 & $0.42^{\text {ns }}$ \\
\hline & $\mathrm{b}^{*}$ & 35.41 & 3 & 11.80 & $1.10^{\mathrm{ns}}$ \\
\hline \multirow{3}{*}{ Duration } & $\mathrm{L}^{*}$ & 1257.57 & 2 & 628.79 & $21.89^{* *}$ \\
\hline & $a^{*}$ & 1.43 & 2 & 0.72 & $0.10^{\text {ns }}$ \\
\hline & $b^{*}$ & 2.67 & 2 & 1.33 & $0.12^{\text {ns }}$ \\
\hline \multirow{3}{*}{ Wood Types } & $\mathrm{L}^{*}$ & 6537.30 & 1 & 6537.30 & $227.60^{* *}$ \\
\hline & $a^{*}$ & 94.80 & 1 & 94.80 & $12.82^{* *}$ \\
\hline & $b^{*}$ & 294.70 & 1 & 294.70 & $27.55^{* *}$ \\
\hline \multirow{3}{*}{ Sampling Height } & $\mathrm{L}^{*}$ & 222.61 & 2 & 111.31 & $3.88^{*}$ \\
\hline & $a^{*}$ & 0.78 & 2 & 0.39 & $0.05^{\mathrm{ns}}$ \\
\hline & $b^{*}$ & 23.77 & 2 & 11.89 & $1.11^{\mathrm{ns}}$ \\
\hline
\end{tabular}

Note: $\quad * *=$ significant difference at $\mathrm{p} \leq 0.01$,

* = significant difference at $\mathrm{p} \leq 0.05$

ns $=$ not significant

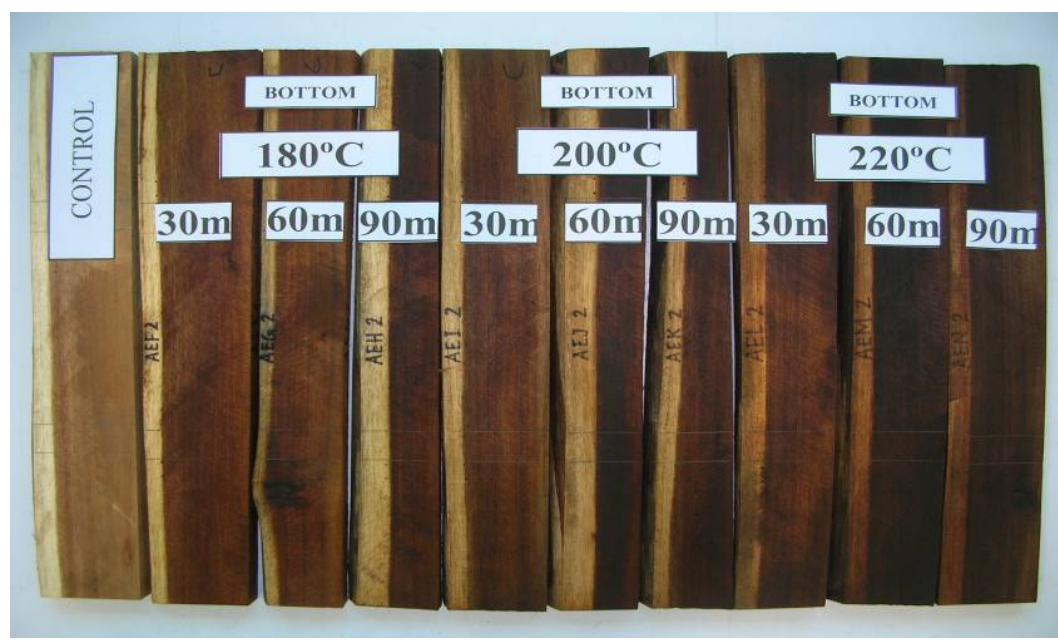

Figure 1. Colour of treated Acacia hybrid (bottom) 


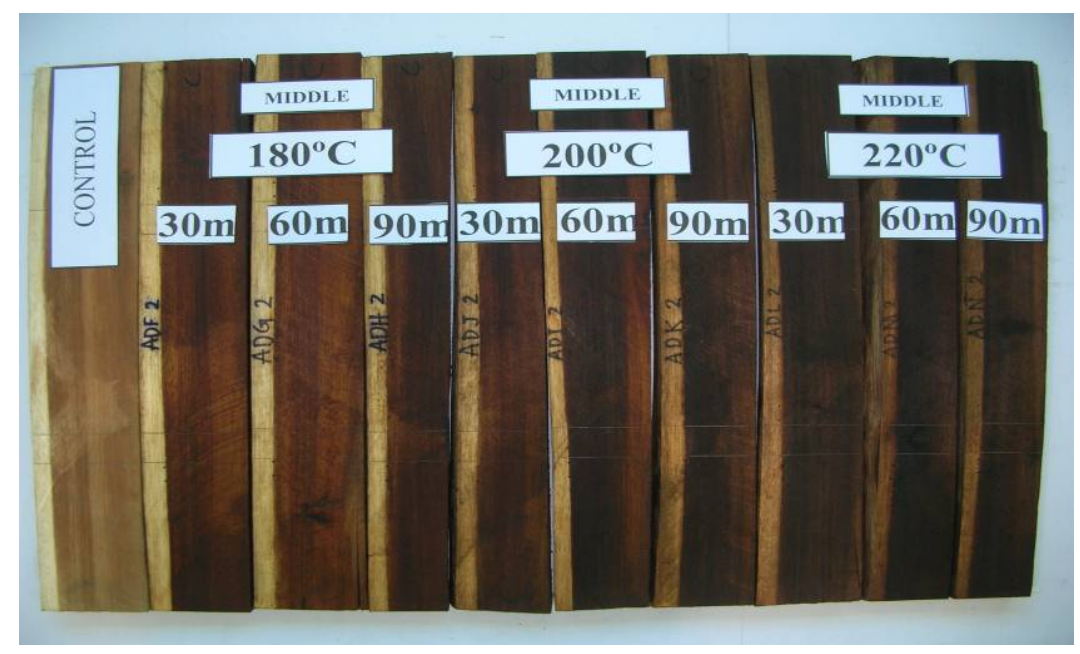

Figure 2. Colour of treated Acacia hybrid (middle)

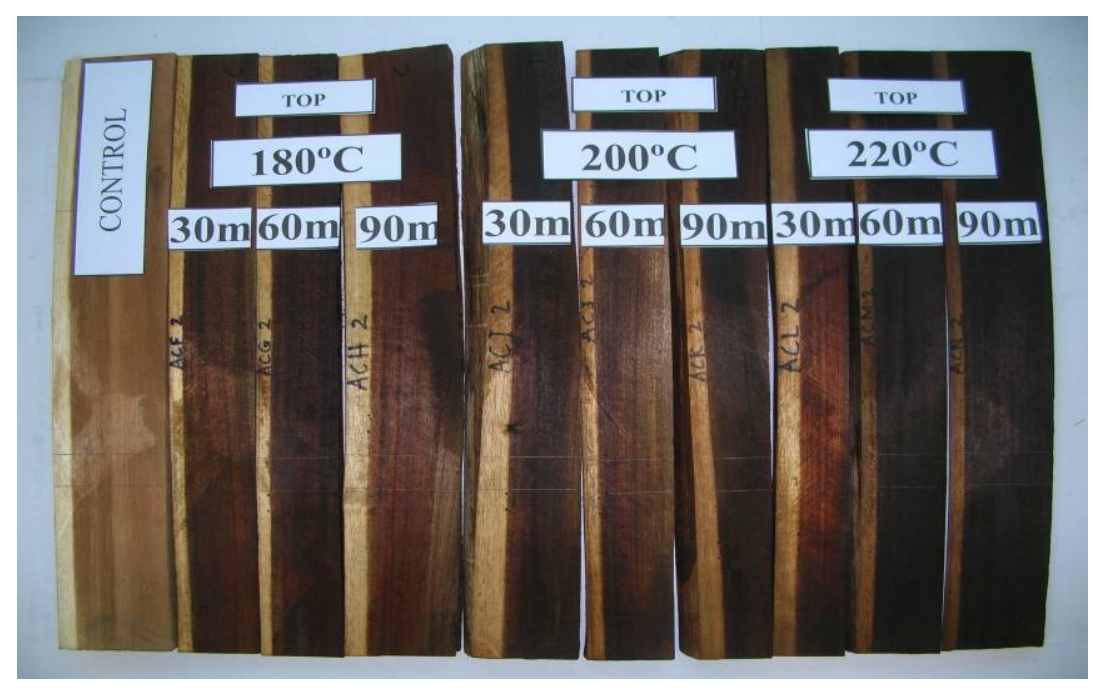

Figure 3. Colour of treated Acacia hybrid (top) 


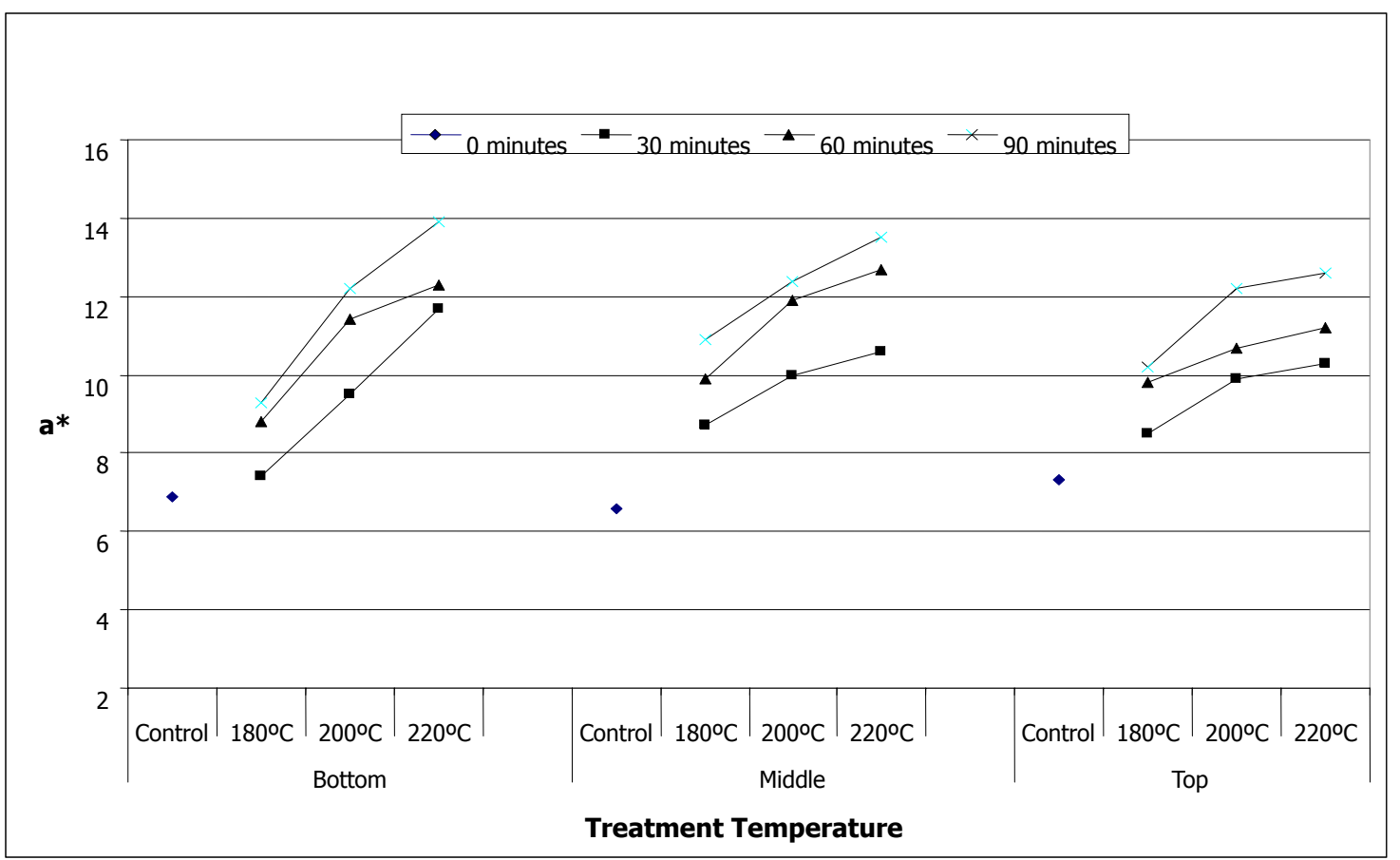

Figure 4. Average values in reddish $\left(\mathrm{a}^{*}\right)$ of treated sapwood

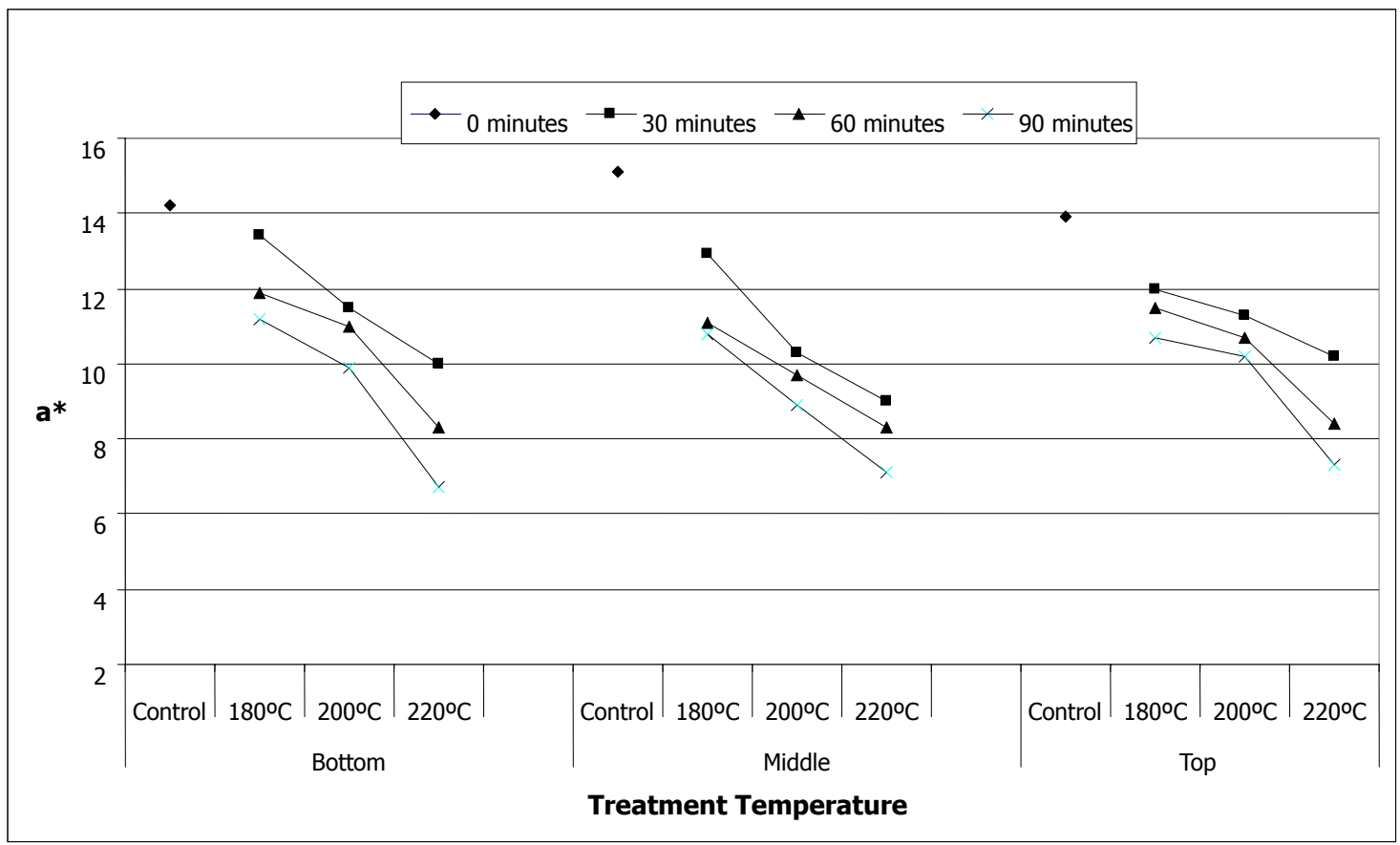

Figure 5. Average values in reddish $\left(a^{*}\right)$ of treated heartwood 


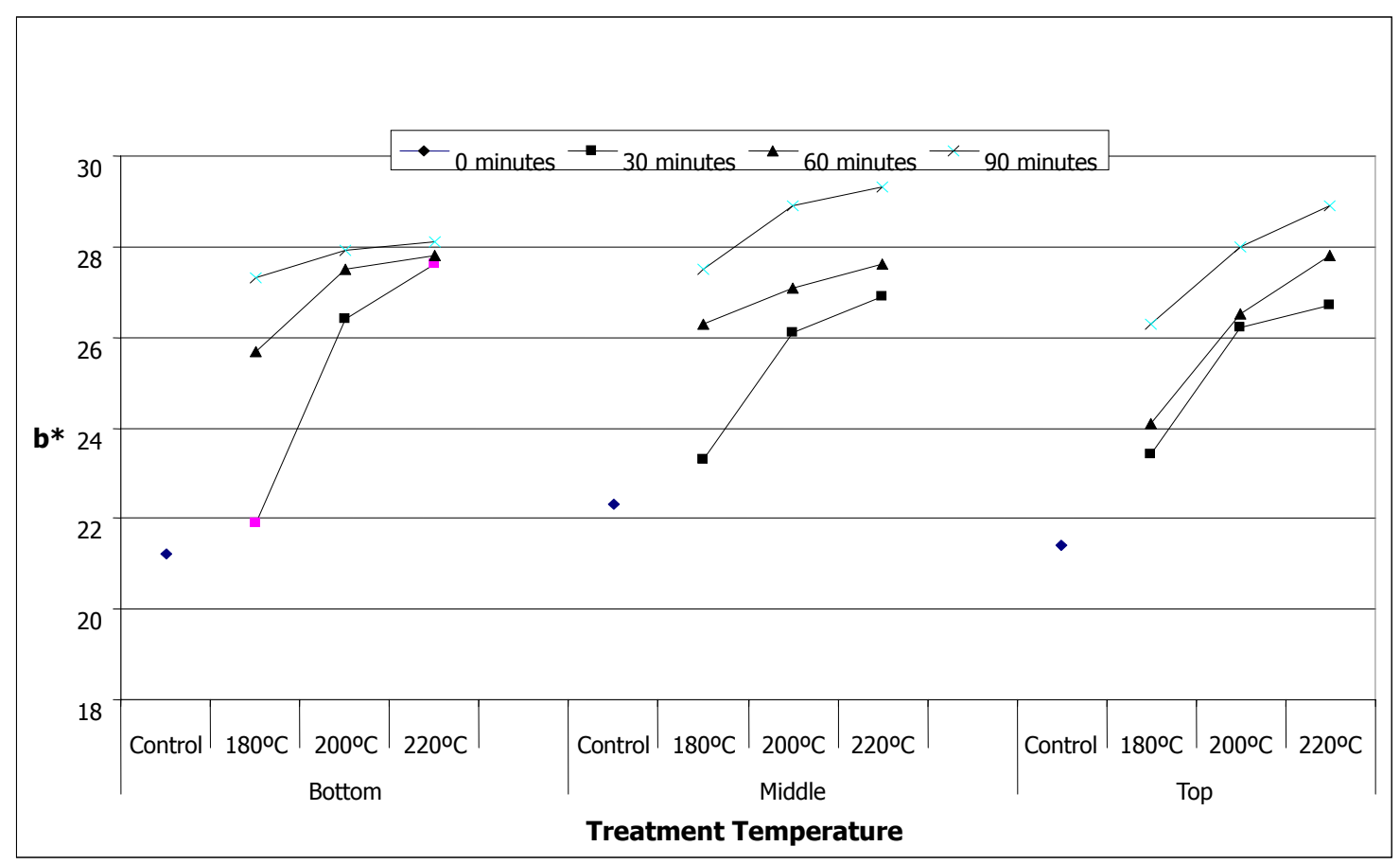

Figure 6. Average values in yellowish $\left(\mathrm{b}^{*}\right)$ of treated sapwood

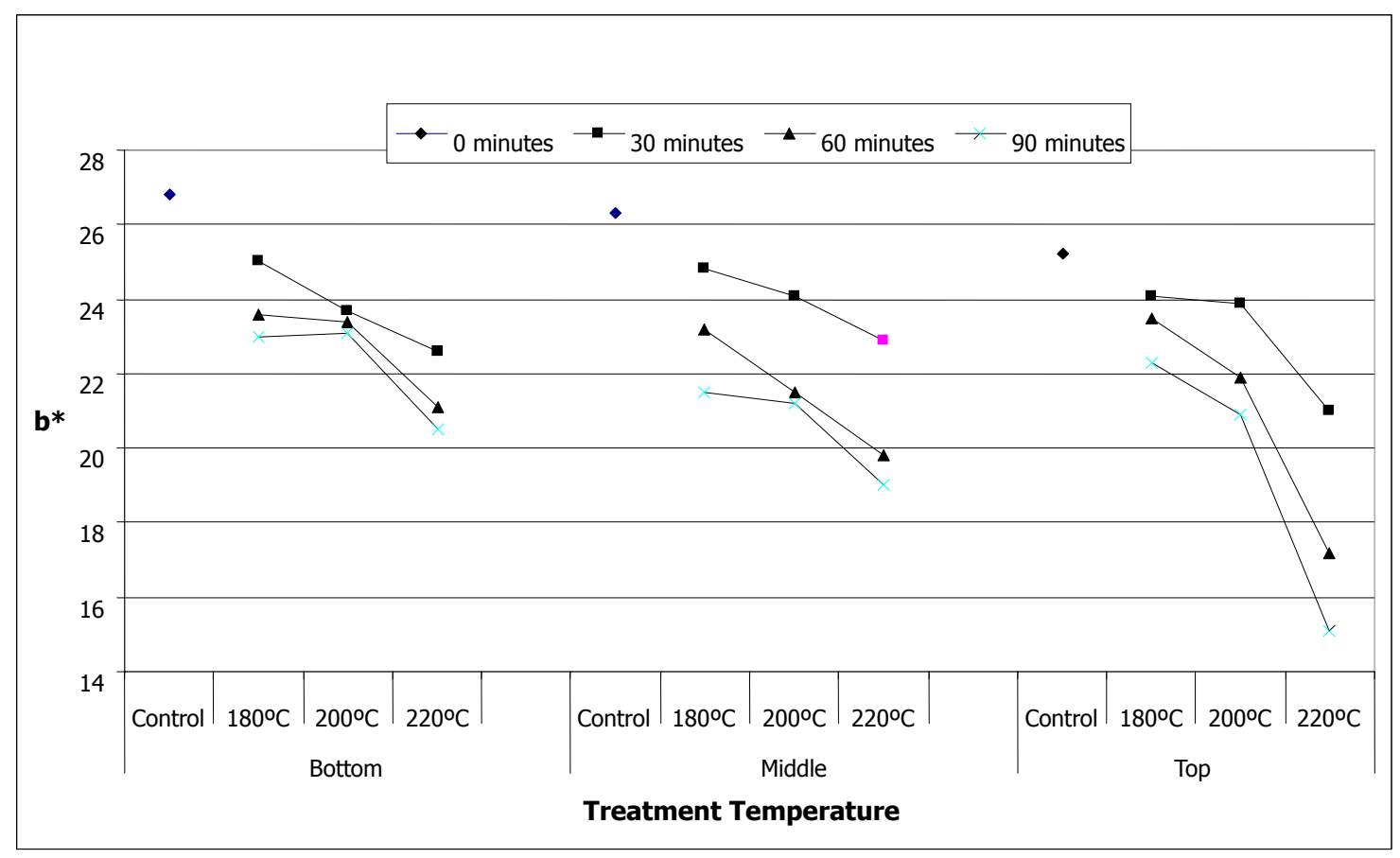

Figure 7. Average values in yellowish $\left(b^{*}\right)$ of treated heartwood 


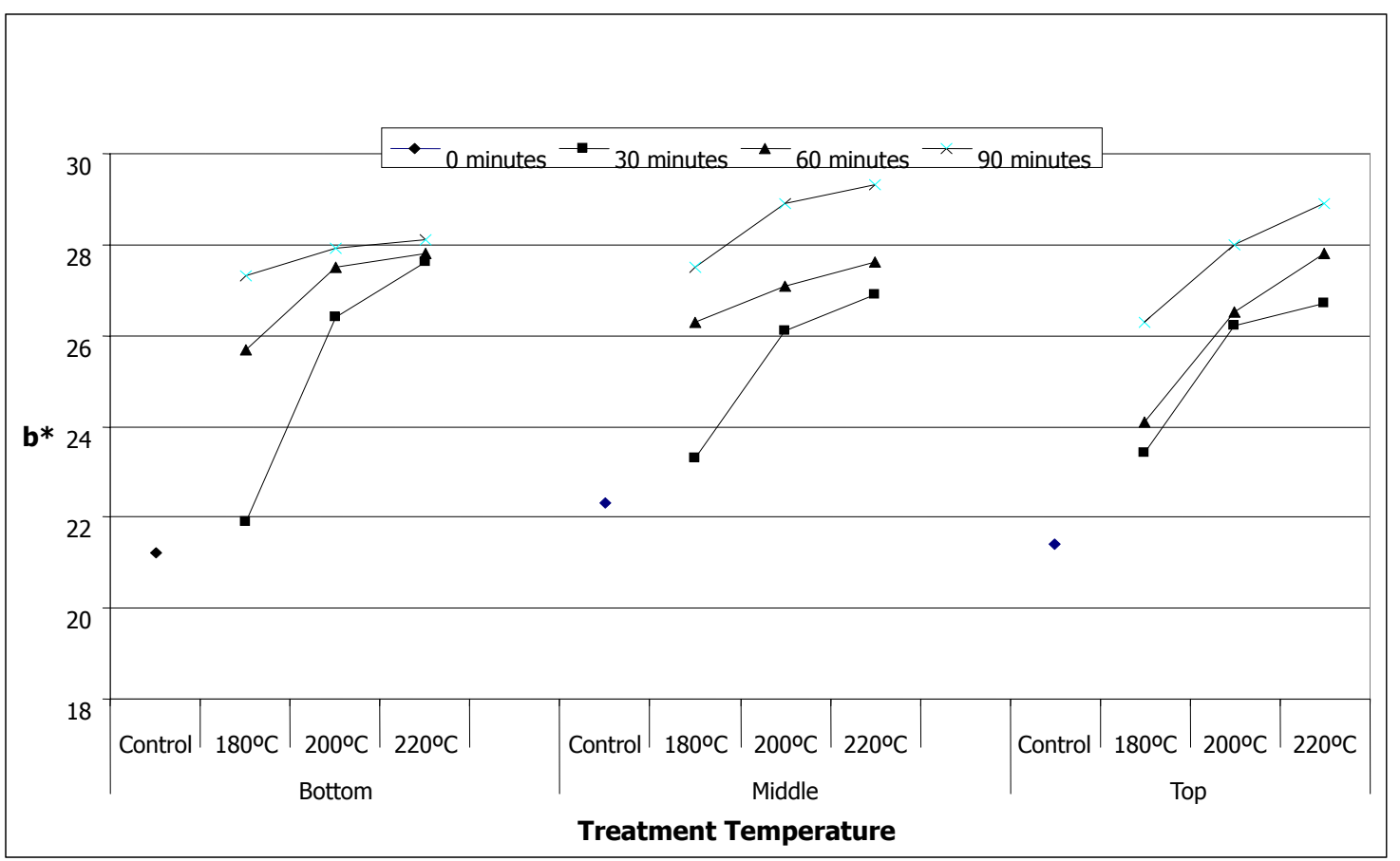

Figure 8 . Average values in yellowish $\left(\mathrm{b}^{*}\right)$ of treated sapwood

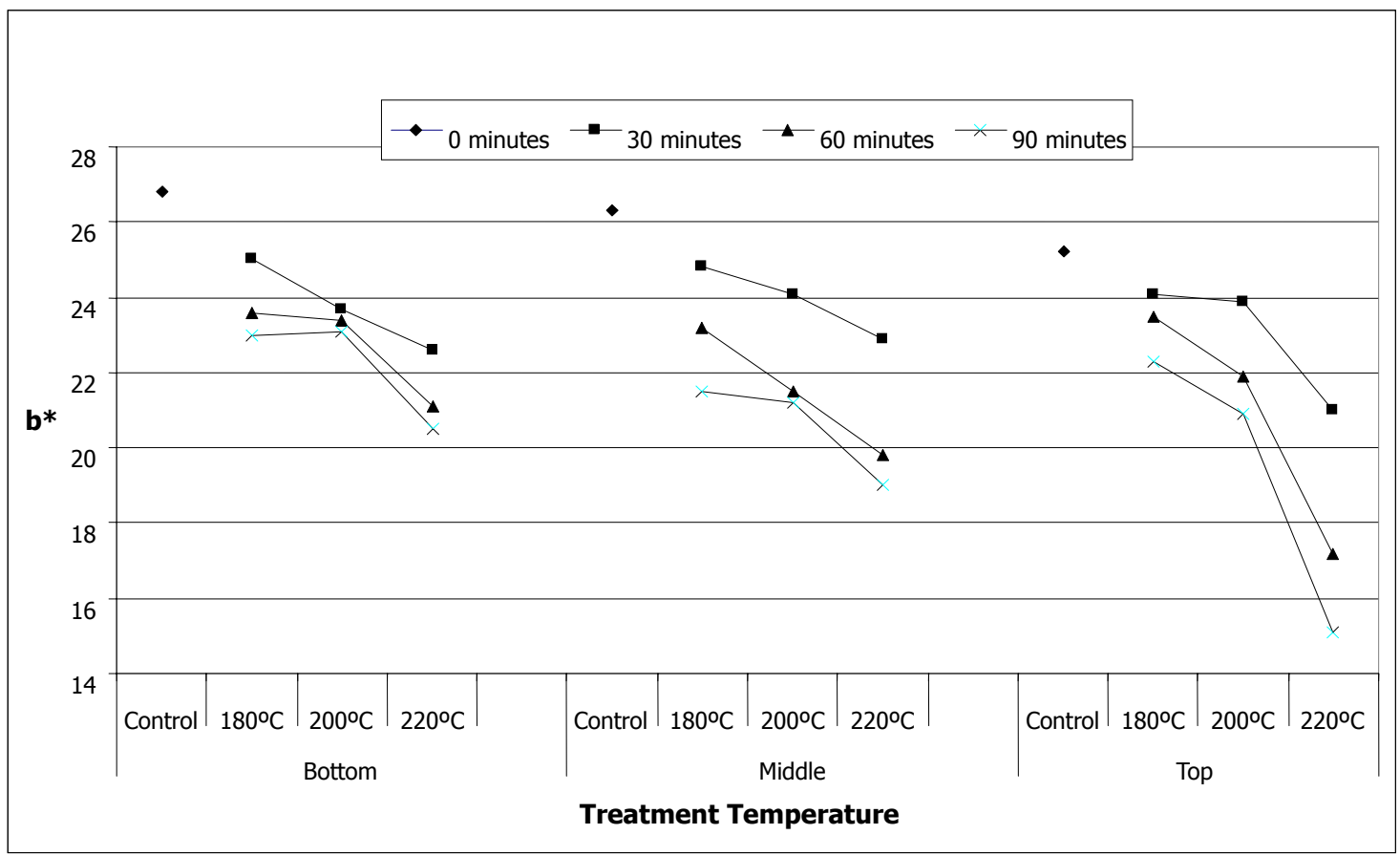

Figure 9. Average values in yellowish ( $\left.b^{*}\right)$ of treated heartwood 